\title{
Effect of Fusion/Activation Protocol on In Vitro Development of Porcine Nuclear Transfer Embryos Constructed with Foreign Gene-Transfected Fetal Fibroblasts
}

\author{
Mario A. MARTINEZ DIAZ ${ }^{1)}$, Tadashi MORI ${ }^{2)}$, Masashi NAGANO ${ }^{1)}$, Seiji KATAGIRI ${ }^{1)}$ and Yoshiyuki TAKAHASHI ${ }^{1) *}$ \\ ${ }^{1)}$ Laboratory of Theriogenology, Department of Veterinary Clinical Sciences, Graduate School of Veterinary Medicine, Hokkaido \\ University, Sapporo 060-0818 and ${ }^{2)}$ Animal Breeding and Reproduction, Division of Bioresources and Product Science, Graduate School \\ of Agriculture, Hokkaido University, Sapporo 060-8589, Japan
}

(Received 20 January 2003/Accepted 10 June 2003)

\begin{abstract}
The effect of fusion/activation protocol on in vitro development of porcine nuclear transfer (NT) embryos constructed with foreign gene-transfected somatic cells were investigated. NT embryos were produced by using enucleated M II oocytes and enhanced green fluorescence protein (EGFP) gene-transfected or non-transfected porcine fetal fibroblasts. One group of NT embryos received a single electrical pulse to induce fusion and activation simultaneously (FAS). The other group was fused 2 hr before activation (FBA) using two kinds of electrical pulses. Electrically activated NT embryos in both groups were treated with cycloheximide (CHX) before culture to assess the development to the blastocyst stage. After 6 days of culture, all morulae and blastocysts derived from EG FP-transfected fibroblasts emitted green fluorescence without mosaicism, and EGFP-gene product was also detected in all morulae and blastocysts examined. NT embryos undergoing FAS showed higher developmental capacity to blastocysts than those undergoing FBA, regardless of the EGFP transfection into the nuclear donor cells. The results also indicated that EGFP-gene transfection into nuclear donor cells has no obvious deleterious effect on the development of NT embryos to blastocysts. KEY WORDS: cycloheximide, green fluorescence protein, nuclear transfer, swine, transgenic embryo.
\end{abstract}

J. Vet. Med. Sci. 65(9): 989-994, 2003

Transgenic (TG) farm animals have been routinely produced by pronuclear injection of foreign DNA into fertilized oocytes; however, embryo survival and transgene integration efficiencies are very poor [5]. Since the famous cloned sheep "Dolly" was born [27], nuclear transfer (NT) technology has become another methodology available for the production of TG animals. TG offspring derived from the NT embryos constructed with foreign gene-transfected somatic cells have been produced in sheep [20], cattle [4], goats [9] and pigs [17]. In the pig, however, somatic cell NT technology is still inefficient, and the factors affecting the success in the production of porcine NT embryos have to be explored.

Somatic cell NT embryos have been most commonly produced by using enucleated oocytes at the metaphase II (M II) and various kinds of differentiated cells (nuclear donor cells) at the G0/G1 phase. A couplet of M II oocyte and nuclear donor cell is fused by adding an electric stimulation. Fused couplets are then subjected to an artificial activation to replace the fertilization process and to enter the first mitotic division. Fusion/activation process has been reported to critically affect the development of NT embryos. The NT embryos fused several hours before activation (termed 'FBA' in the present paper) showed higher development to the blastocyst stage than those fused and activated simultaneously (termed 'FAS' in the present paper) in mice [25], cattle [21, 26] and pigs [11]. These observation indicated that prolonged exposure of transplanted nuclei at the

\footnotetext{
* Correspondence to: Takahashi, Y., Laboratory of Theriogenology, Department of Veterinary Clinical Sciences, Graduate School of Veterinary Medicine, Hokkaido University, Sapporo 060-0818, Japan.
}

G0/G1 stage to high M-phase promoting factor (MPF) activity may play an important role in the reprogramming and development of NT embryos. However, our previous study [13] demonstrated that porcine NT embryos undergoing FAS had a higher percentage of blastocysts than those undergoing FBA at 1.5- to 4.5-hr intervals when NT embryos were treated with cycloheximide (CHX) after electrical activation stimuli. In our previous study, we produced porcine NT embryos by using enucleated M II oocytes and serum-starved cumulus cells presumably at the G0/G1 phase [13]. Therefore, it is necessary to prove the superiority of the fusion/activation protocol of FAS with $\mathrm{CHX}$ treatment over that of FBA with CHX treatment in the development of NT embryos constructed with other types of somatic cells, especially with the foreign gene-transfected somatic cells.

Enhanced green fluorescence protein (EGFP) gene has been used as a reliable reporter gene for the selection and confirmation of foreign gene-transfected cells [7, 8]. TG sheep [14, 20], cattle [4] and goats [9] were produced through the NT procedure by using the somatic cells transfected with specific foreign genes in combination with EGFP gene by using a lipofection procedure. Porcine TG embryos [11, 18, 24] and offspring [12,17] have been also produced through NT technology by using the somatic cells which were transfected with EGFP gene by a replicationdefective viral vector.

The present study was conducted to verify the efficacy of the fusion/activation protocol of FAS with CHX treatment in the production of porcine TG embryos through NT procedure and to determine the effect of EGFP gene-transfection into the nuclear donor cells by a lipofection method on the 
development of NT embryos. We also examined the expression of octamer-binding transcription factor-4 (Oct-4) gene in the NT/TG embryos as a marker of reprogramming of donor nuclei. Oct-4 gene is presumed to be a critical factor controlling preimplantation embryonic development in mammals and not expressed in the differentiated somatic cells $[6,15]$.

\section{MATERIALS AND METHODS}

Preparation of recipient oocytes: In vitro matured oocytes derived from slaughterhouse ovaries of prepubertal gilt were used as recipient cytoplasts. In vitro maturation was performed as described previously [3]. Briefly, oocytecumulus-granulosa cell complexes collected from dissected antral follicles were cultured in bovine serum albumin (BSA)-free North Carolina State University Medium 23 (NCSU-23) [19] supplemented with $0.57 \mathrm{mM}$ cysteine (Sigma Chemical Co., St. Louis, MO, U.S.A.), 10\% porcine follicular fluid, $10 \mathrm{IU} / \mathrm{m} l$ equine chorionic gonadotropin (Serotropin, Teikoku Hormone Mfg. Co., Ltd., Tokyo, Japan), $10 \mathrm{IU} / \mathrm{m} l$ human chorionic gonadotropin (Gonatropin, Teikoku Hormone) and $50 \mu \mathrm{g} / \mathrm{m} l$ gentamicin sulfate (Sigma) for $20 \mathrm{hr}$ under a humidified atmosphere with 5\% $\mathrm{CO}_{2}$ in air at $39^{\circ} \mathrm{C}$. This was followed by culture in the same medium without hormones for additional $22 \mathrm{hr}$. After the maturation culture, oocytes were freed of granulosa/ cumulus cells by vortexing in $\mathrm{Ca}^{2+}-$ and $\mathrm{Mg}^{2+}$-free Dulbecco's phosphate-buffered saline (DPBS) containing $0.1 \%$ hyaluronidase (Sigma).

The enucleation of oocytes was done as described previously [2]. In brief, the oocytes with the first polar body were enucleated by aspirating the first polar body and adjacent cytoplasm (around 20\%) in $25 \mathrm{mM}$ Hepes-buffered TCM199 (Sigma) supplemented with $10 \%$ fetal calf serum (FCS, Gibco Laboratories, Grand Island, NY, U.S.A.) and 5 $\mu \mathrm{g} / \mathrm{m} l$ cytochalasin B (Sigma). The manipulated oocytes were incubated in $\mathrm{Ca}^{2+}$ - and $\mathrm{Mg}^{2+}$-free DPBS supplemented with $5 \mu \mathrm{g} / \mathrm{m} l$ Hoechst 33342 (Sigma) and $3 \mathrm{mg} / \mathrm{ml}$ BSA (fatty acid-free, Sigma) for $20 \mathrm{~min}$ at $39^{\circ} \mathrm{C}$. Enucleation was confirmed by exposing the oocytes to ultraviolet light under an inverted microscope (Eclipse TE 300, Nikon, Tokyo, Japan) equipped with an epifluorescence (TE-FM, Nikon) and UV-1A filter block (365 nm excitation and 400 nm emission).

Preparation of nuclear donor cells: Porcine fetal fibroblasts used as nuclear donor cells were prepared as followings. A primary culture of fetal fibroblasts was established from a fetus of approximately 60 days old. The fetus was washed several times in sterile physiological saline. Fetal skin tissues were minced with a pair of scissors, and cultured in Dulbecco's modified Eagle's medium: Ham's F12 nutrient mixture (DMEM/F12, Gibco) supplemented with $10 \% \mathrm{FCS}$ and $50 \mu \mathrm{g} / \mathrm{m} l$ gentamicin sulfate at $37^{\circ} \mathrm{C}$ in a humidified air with $5 \% \mathrm{CO}_{2}$. After being passaged up to three times, the cells were cryopreserved using a cell freezing solution (BAMBANKER ${ }^{\mathrm{TM}}$, Nippon Genetic Co., Ltd.,
Tokyo, Japan) and stored in liquid nitrogen according to the manufacturer's protocol.

EGFP gene transfection into fetal fibroblasts: Frozenthawed fetal fibroblasts were transfected with pCXN-EGFP [17] containing a G418 resistant cartridge using LipoTAXI Mammalian Transfection Kit (Strategene, La Jolla, CA, U.S.A.) according to the manufacturer's instructions. Briefly, $300 \mu l$ of LipoTAXI reagent and $2.7 \mathrm{~m} l$ of DMEM/ F12 were mixed and settled for $30 \mathrm{~min}$ at room temperature before dilution with $5 \mathrm{ml}$ of DMEM/F12 containing $30 \mu \mathrm{g}$ vector. Sub-confluent fetal fibroblasts were incubated with this preparation for $5 \mathrm{hr}$ in a 100-mm culture dish (Falcon 3803, Becton and Dickinson Labware, Franklin Lakes, NJ, U.S.A.), followed by the addition of $1 \mathrm{ml}$ of FCS. After FCS and culture for $24 \mathrm{hr}$, the cells were transferred to nine 60-mm dishes (Falcon 3802) and further cultured in DMEM/F12 supplemented with $10 \%$ FCS until confluent. Once cells grew to reach confluence, a primary cell selection was performed by culturing for one week in DMEM/ F12 supplemented with $10 \% \mathrm{FCS}, 10 \mathrm{ng} / \mathrm{ml}$ recombinant human basic fibroblast growth factor (Collaborative Biomedical Products, Two Oak, Bedford, MA, U.S.A.), $10 \mu \mathrm{g} /$ $\mathrm{m} l$ insulin (Gibco) and $400 \mu \mathrm{g} / \mathrm{m} l$ Geneticin $^{\mathrm{R}}$ (G418, Gibco). The cells were further cultured for 3 days in DMEM/F12 containing 10\% FCS and $600 \mu \mathrm{g} / \mathrm{m} l \mathrm{G} 418$ followed by the additional 3- to 10-day culture in the same medium without G418. These successive cell cultures with and without G418 were repeated three times to select the G418-resistant cells. After the third replication of successive cultures, the grown cells were frozen-stored until use.

Production of NT embryos: Frozen-thawed fibroblasts were cultured in DMEM/F12 supplemented with $0.5 \%$ FCS and $50 \mu \mathrm{g} / \mathrm{m} l$ gentamicin sulfate for 3-4 days (serumstarved culture). After a standard trypsinization, serumstarved fibroblasts were inserted individually into the perivitelline space of enucleated oocytes through the same slit in the zona pellucida as was made during enucleation. After being kept in NCSU-23 for 20-30 min, manipulated couplets were placed and manually aligned between two wire electrodes, $1.0-\mathrm{mm}$ apart, overlaid with $1 \mathrm{ml}$ of $0.3 \mathrm{M}$ mannitol solution containing $0.1 \mathrm{mM} \mathrm{CaCl}$ and $0.1 \mathrm{mM}$ $\mathrm{MgSO}_{4}$. DC pulses were delivered to the electrodes using an electrical cell fusion instrument (LF 100, Life Tec Co., Tokyo, Japan) to induce fusion and/or activation. One group of couplets received a single pulse of $150 \mathrm{~V} / \mathrm{mm}$ for $100 \mu \mathrm{sec}$ (activation pulse) to induce fusion and activation simultaneously (FAS). After incubation for $30 \mathrm{~min}$ in NCSU-23, fused couplets in this group were cultured for 5 $\mathrm{hr}$ in NCSU-23 supplemented with $10 \mu \mathrm{g} / \mathrm{m} l$ of cycloheximide (CHX, Sigma). Another group of couplets was fused before activation (FBA) as followings. They were first induced fusion by a single DC pulse of $150 \mathrm{~V} / \mathrm{mm}$ for 25 $\mu$ sec (fusion pulse) and kept in NCSU-23 for $2 \mathrm{hr}$ before subjecting to the activation pulse (a single DC pulse of 150 $\mathrm{V} / \mathrm{mm}$ for $100 \mu \mathrm{sec}$ ). Fusion rate in this group was determined $30 \mathrm{~min}$ after the fusion pulse. Two hours after giving the fusion pulse, the fused couplets were transferred to 
NCSU-23 containing $10 \mu \mathrm{g} / \mathrm{m} l$ of CHX and cultured for 5 hr.

Evaluation of in vitro development of NT embryos: After the CHX treatment, NT embryos both in FAS and FBA groups were cultured in 30- $\mu l$ drops of NCSU-23 covered with paraffin oil at $39^{\circ} \mathrm{C}$ in a humidified air with $5 \% \mathrm{CO}_{2}$. The cleavage and development to the blastocyst stage were examined after 2 and 6 days of culture, respectively. At the end of culture, the cell numbers in the blastocysts were examined using an air-dry method as described elsewhere [22]. Blastocyst cell numbers were also counted by staining with $5 \mu \mathrm{g} / \mathrm{m} l$ of Hoechst 33342 when NT blastocysts were assigned for the RT-PCR analysis.

Evaluation of EGFP fluorescence: EGFP expression in the gene-transfected fibroblasts and NT embryos was determined using an epifluorescence microscopes (Eclipse TE 300 with a standard FITC filter, Nikon, Tokyo, Japan or Olympus IX70 with NIBA, Tokyo, Japan).

RT-PCR assay: The NT embryos developed to the morula and blastocyst stages were transferred into DPBS containing $0.1 \%$ pronase (Actinase E, Kaken Pharmaceutical Co., Tokyo, Japan) to remove the zona pellucida. They were then washed several times in DPBS containing $1 \%$ polyvinyl alcohol (PVA, Sigma). Each embryo was transferred into a PCR tube with a minimum volume (approximately 2 $\mu l$ ) of DPBS supplemented with $1 \%$ PVA. After adding $5 \mu l$ of lysis buffer composed by $0.8 \%$ Igepal (ICN, SevenHills, New South Wales, Australia), $5 \mathrm{mM}$ DTT and $0.125 \mu \mathrm{l}$ of RNase inhibitor (40 U/ $\mu l$, Wako Pure Chemical Industries, Ltd., Osaka, Japan), the PCR tubes were snap-frozen in liquid nitrogen and stored at $-80^{\circ} \mathrm{C}$. Reverse transcription (RT) was performed as described previously [6]. Briefly, PCR tubes containing embryos were heated at $80^{\circ} \mathrm{C}$ for 5 $\mathrm{min}$ and then placed in ice for $3 \mathrm{~min}$, prior to RT. Followings were added to the tube: $2.0 \mu l$ of $5 \times$ first strand buffer, $0.5 \mu l$ of $0.1 \mathrm{M}$ DTT, $0.5 \mu l$ of Oligo $(\mathrm{dT})_{15}(0.5 \mu \mathrm{g} / \mu l), 0.5$ $\mu l$ of $10 \mathrm{mM}$ dNTP and $0.25 \mu l$ of RNase inhibiter $(40 \mathrm{U} / \mu l)$. After denaturation by heating at $65^{\circ} \mathrm{C}$ for $5 \mathrm{~min}$, the samples were kept at $37^{\circ} \mathrm{C}$ for $10 \mathrm{~min}$ and $0.5 \mu \mathrm{l}$ of reverse transcriptase (SuperScript, $200 \mathrm{U} / \mathrm{m} l$, Gibco) was added to the tube. The tubes were incubated at $37^{\circ} \mathrm{C}$ for $1 \mathrm{hr}$. Reverse transcriptase was inactivated by heating at $99^{\circ} \mathrm{C}$ for $5 \mathrm{~min}$ and the samples were stored at $-20^{\circ} \mathrm{C}$ until use.

First strand cDNA, equivalent to a half of a single embryo (3-4 $\mu l$ ), was transferred to a PCR tube. PCR amplification was performed in a total volume of $50 \mu \mathrm{l}$ using KOD-Plus DNA polymerase (Toyobo Co., Ltd., Osaka, Japan) or Expand High Fidelity PCR System (Roche Molecular Biochemicals, Mannheim, Germany). For the amplification of EGFP gene, the sense primer 5'-GTCGAGCTGGACGGCGACGTA-3' and antisense primer 5'-CACGAACTCCAGCAGGACCATG-3' were used to generate a 627 bp cDNA transcript. To confirm the expressed EGFP transcript was not originated from the contaminated vector DNA in the cDNA samples, PCR was performed to detect a part of untranslated vector sequence, chicken $\beta$-actin promoter sequence, using the sense primer 5'-CACGTTCTGCT-
TCACTCTCC-3' and antisense primer 5'-CTTGGTTTTTATAGGGCCG-3'.

For $O c t-4$ gene, the sense primer 5'-CTCGAACAATTTGCCAAGCTCC-3' and antisense primer 5'TACAGGGTGGTGAAGTGAGG-3' were used to generate putative 563 bp cDNA transcript (position in exon 2 and exon 5 of the porcine genomic sequence of EMBL accession number AJ251914). Denaturation of the samples was done at $95^{\circ} \mathrm{C}$ for $5 \mathrm{~min}$. The thermocycling condition consisted of 45 cycles of the following three steps: at $95^{\circ} \mathrm{C}$ for $30 \mathrm{sec}$ (denaturing); at $54^{\circ} \mathrm{C}$ for $1 \mathrm{~min}$ for EGFP or $60^{\circ} \mathrm{C}$ for $45 \mathrm{sec}$ for Oct-4 (annealing); and at $72^{\circ} \mathrm{C}$ for $30 \mathrm{sec}$ (extension). PCR products were concentrated with ethanol and dissolved in $15 \mu \mathrm{l}$ of TE. Of those concentrated PCR products, $10 \mu \mathrm{l}$ was separated with $1 \%$ agarose gel electrophoresis in Trisborate-EDTA buffer. Specificity of each amplicon was confirmed by staining the gel with $0.5 \mu \mathrm{g} / \mathrm{m} l$ ethidium bromide (Wako). The presence of Oct-4 gene expression in the NT embryos and the somatic cells was confirmed by nested PCR using the sense primer 5'-AGAACATGTGTAAGCTGCGGC-3', antisense primer 5'-ACTGCAGGAACATGCTCTCCA-3' (position in exon 3 and exon 4) and amplicons ( $3 \mu l$ of concentrated 1st PCR products) as templates. The sequence of nested-PCR products was determined by using an auto-fluorescence sequencer (DSQ2000L/2000S, Shimadzu Co., Ltd., Kyoto, Japan).

Experimental design: In the preliminary experiment, the efficiency of LipoTAXI reagent on the transfection of EGFP gene to the fetal fibroblasts was examined. Sub-confluent cultures of fibroblasts in 35-mm culture dishes were incubated for $24 \mathrm{hr}$ with 1 or $2 \mu \mathrm{g}$ DNA and $24 \mu \mathrm{l}$ of LipoTAXI reagent, according to the manufacturer's instructions. Two days after the transfection treatment, the cells were stained with $5 \mu \mathrm{g} / \mathrm{m} l$ Hoechst 33342. The proportion of the cells with positive fluorescence was calculated based on the number of cells stained with Hoechst 33342.

The next experiment was conducted to determine the effects of fusion/activation protocol and EGFP gene transfection into the nuclear donor cells on the subsequent in vitro development of porcine NT embryos. EGFP gene transfection into the fibroblasts was done using $2 \mu \mathrm{g}$ DNA in this experiment. EGFP fluorescence expression in the cells selected for the nuclear donor cells was determined after the successive culture with and without G418 and subsequent serum-starvation culture as described above. The couplets of enucleated oocytes and either EGFP gene-transfected and non-transfected fibroblasts were subjected to NT using FAS or FBA protocol. The NT embryos developed to the morula and blastocyst stages were subjected to the determination of EGFP fluorescence expression. Some of the morulae and blastocysts were also assigned for the RT-PCR to analyze the expression of EGFP and Oct-4 genes.

Statistical analysis: Data on the rates of fusion, cleavage and subsequent development to the blastocyst stage were subjected to two-way ANOVA using StatView software (Abacus Concepts Inc., Berkeley, CA, U.S.A.). 


\section{RESULTS}

Transfection rate of EGFP gene after 2-day culture of fibroblasts was very low $(1.7 \pm 0.5 \%$, mean \pm SD of 5 replicates) in the preliminary experiment. However, after the successive selection culture, all of the fibroblasts, which were stained with Hoechst 33342, emitted green fluorescence under an epifluoresence microscope (Fig. 1).

There were no interaction between the effects of fusion/ activation protocol and $E G F P$ gene transfection into the nuclear donor cells on the in vitro development of NT embryos $(P>0.1)$. As shown in Table 1, no deleterious effect of EGFP transfection into the nuclear donor cells was observed in all criteria determined, regardless of the fusion/ activation protocol. FAS gave a higher fusion rate than FBA $(P<0.05)$. Fusion/activation protocol did not affect the cleavage rate of NT embryos $(P>0.1)$; however, NT embryos in the FAS group showed higher development to the blastocyst stage than those in the FBA group, regardless of gene transfection $(P<0.01)$.

The expression of EGFP fluorescence was detected without mosaicism in all morulae $(\mathrm{n}=10)$ and blastocysts $(\mathrm{n}=$ 13) derived from the NT embryos constructed with genetransfected fibroblasts, regardless of the fusion/activation protocol (Fig. 2). EGFP-gene product was also detected in all morulae $(\mathrm{n}=6)$ and blastocysts $(\mathrm{n}=4)$ derived fromEGFP gene-transfected fibroblasts, regardless of the fusion/activation protocol (Fig. 3). Chicken $\beta$-actin promoter sequence in the sample was less than detectable amount. None of the NT embryos derived from non-transfected fibroblasts showed the expression of EGFP fluorescence.

The sequence of PCR products agreed to that expected from the primer set used to amplify Oct-4 gene. Expression of mRNA of Oct-4 gene was confirmed in morulae $(\mathrm{n}=6)$ and blastocysts $(\mathrm{n}=2)$ originated from $E G F P$ gene-transfected fibroblasts (Fig. 3); while, none of fibroblasts used as

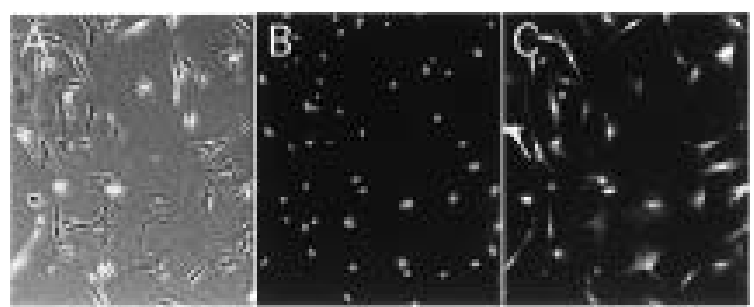

Fig. 1. Expression of EGFP fluorescence in fetal fibroblast cells. Pictures viewed under a light microscope (A), and those of the same cells with Hoechst 33342 (B) and under an epifluoresence microscope (C).
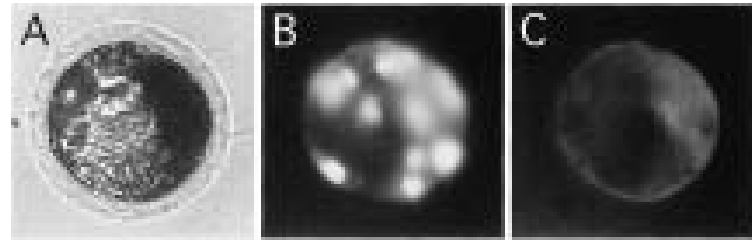

Fig. 2. Expression of EGFP fluorescence in a nuclear transfer embryo at the blastocyst stage derived from EGFP gene-transfected fetal fibroblasts. Pictures viewed under a light microscope (A), and those of the same embryo stained with Hoechst 33342 (B) and under an epifluoresence microscope (C).

nuclear donor cells expressed mRNA of $O c t$-4 gene.

\section{DISCUSSION}

A high rate of fusion in the FAS group might be due to the longer duration of the electrical pulse of $150 \mathrm{v} / \mathrm{mm}$ for 100 $\mu \mathrm{sec}$ (activation pulse) compared with that of $150 \mathrm{v} / \mathrm{mm}$ for $25 \mu$ sec (fusion pulse) applied in the FBA group at fusion. An increase in the pulse duration was reported to improve

Table 1. Effects of fusion/activation protocol and enhanced green fluorescence protein (EGFP) gene transfection of nuclear donor cells on the in vitro development of porcine nuclear transfer embryos

\begin{tabular}{|c|c|c|c|c|c|c|}
\hline \multirow{2}{*}{$\begin{array}{c}\text { Fusion/ } \\
\text { activation } \\
\text { protocol }^{\mathrm{A})}\end{array}$} & \multirow{2}{*}{$\begin{array}{c}\text { Nuclear } \\
\text { donor } \\
\text { cell }\end{array}$} & \multirow{2}{*}{$\begin{array}{c}\text { No. of } \\
\text { couplets } \\
\text { (replicates) }\end{array}$} & \multirow{2}{*}{$\begin{array}{l}\% \text { of } \\
\text { fused } \\
\text { couplets }\end{array}$} & \multicolumn{2}{|c|}{$\begin{array}{l}\%^{\mathrm{B})} \text { of embryos } \\
\text { developed to }\end{array}$} & \multirow{2}{*}{$\begin{array}{l}\text { Cell no. in } \\
\text { blastocysts } \\
\text { (n) }\end{array}$} \\
\hline & & & & $\geq 2$-cell & blastocyst & \\
\hline \multirow{3}{*}{ FAS } & Non-transfected & $\begin{array}{l}62 \\
(3)\end{array}$ & $91.8 \pm 7.4$ & $61.8 \pm 6.4$ & $20.9 \pm 8.2$ & $\begin{array}{c}23.3 \pm 15.9 \\
(11)\end{array}$ \\
\hline & Transfected & $\begin{array}{l}76 \\
(4)\end{array}$ & $93.2 \pm 2.3$ & $77.7 \pm 12.2$ & $13.8 \pm 4.8$ & $\begin{array}{c}18.3 \pm 10.0 \\
(10)\end{array}$ \\
\hline & Total & $\begin{array}{l}138 \\
(7)\end{array}$ & $92.6 \pm 4.6^{\mathrm{a})}$ & $70.9 \pm 12.7$ & $16.8 \pm 7.0^{\mathrm{c})}$ & $\begin{array}{l}20.9 \pm 13.4 \\
\quad(21)\end{array}$ \\
\hline \multirow{3}{*}{ FBA } & Non-transfected & $\begin{array}{l}62 \\
(3)\end{array}$ & $82.3 \pm 1.7$ & $66.8 \pm 14.0$ & $4.1 \pm 3.5$ & $\begin{array}{l}22,31 \\
(2)\end{array}$ \\
\hline & Transfected & $\begin{array}{l}70 \\
(3)\end{array}$ & $88.1 \pm 6.9$ & $73.2 \pm 3.7$ & $4.7 \pm 4.1$ & $\begin{array}{c}22.0 \pm 9.5 \\
\text { (3) }\end{array}$ \\
\hline & Total & $\begin{array}{l}132 \\
(6)\end{array}$ & $85.2 \pm 5.5^{\mathrm{b})}$ & $70.0 \pm 9.8$ & $4.4 \pm 3.5^{\mathrm{d})}$ & $\begin{array}{c}23.8 \pm 7.9 \\
(5)\end{array}$ \\
\hline
\end{tabular}

A) FAS: fusion and activation simultaneously, FBA: fusion $2 \mathrm{hr}$ before activation.

B) $\%$ based on the number of fused couplets.

a, b) and c, d) Values (means \pm SD) with different superscripts in the same column differ significantly $(P<0.05$ and $P<0.01$, respectively). 


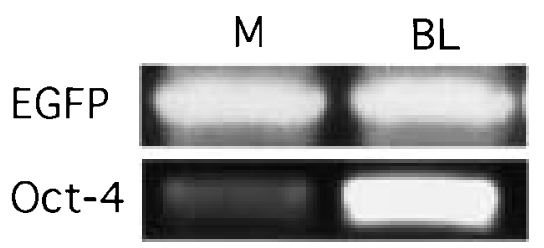

Fig. 3. RT-PCR of nuclear transfer embryos. Representatives of the results of electrophoresis of PCR products of EGFP (627 bp) and Oct-4 (563 bp) genes using each primer set and embryonic cDNA equivalent to a half embryo. Detail is described in materials and methods. M: morula, BL: blastocyst.

the fusion between embryonic cells and enucleated oocytes in cattle [23].

The EGFP gene transfection into the nuclear donor cells and subsequent selection culture showed no obvious deleterious effect on the development of NT embryos to the blastocyst stage, regardless of fusion/activation protocol. This result was in agreement with that in the previous studies, in which porcine fibroblasts $[11,24]$ and bovine granulosa cells [1] were transfected with EGFP gene by a viral infection procedure and used as nuclear donor cells for NT.

Regardless of the EGFP gene transfection to the nuclear donor cells, higher developmental rates of NT embryos to the blastocyst stage were obtained in the FAS group. This finding confirmed the results in our previous study [13], in which we produced porcine NT embryos by using the serum-starved cumulus cells as nuclear donor cells, and the NT embryos undergoing FAS showed higher development to the blastocyst stage than those undergoing FBA at 1.5- to 4.5-hr intervals when NT embryos were treated with $\mathrm{CHX}$. The reason(s) for the superiority of FAS over FBA is obscure. However, in our previous study, the proportion of blastocysts did not differ among the different intervals between fusion and activation, when NT embryos were not treated with CHX [13]. Therefore, the present results support a previous suggestion that $\mathrm{CHX}$-sensitive event(s) occurring shortly after FAS may be responsible for the development of somatic cell NT embryos to the blastocyst stage.

Since chicken $\beta$-actin promoter sequence contaminated in cDNA samples was less than detectable level, EGFP gene in the NT embryos detected by RT-PCR should derived from transcribed mRNA. Similarly, the possibility of amplification of genomic DNA for Oct- 4 could be eliminated since the PCR products showed the expected size and sequence for mRNA but not for genomic DNA. Thus, the PCR products obtained in the present study represent mRNA expression of both genes.

Oct-4 gene was reported to be expressed in murine, porcine and bovine preimplantation embryos $[10,16]$, and in bovine somatic cell NT embryos at the 1-cell to blastocyst stages [6]. The detection of $O c t-4$ gene expression in the present porcine NT/TG embryos suggested a part of reprogramming of donor nuclei. However, further experiments are needed to clarify the normality of gene-transfected NT embryos by improving the development and quality of NT embryos. The development of NT embryos to blastocysts and cell numbers of blastocysts were still poor compared with those of in vivo-grown porcine embryos [28] indicating sub-optimal NT procedures and/or embryo culture conditions.

In conclusion, the present study verified the superiority of FAS followed by the CHX treatment over FBA with CHX treatment in the development of porcine NT embryos constructed with EGPF-transfected and non-transfected fetal fibroblasts. The results also indicate that transfection of EGFP gene into the nuclear donor cells by a lipofection method may have no deleterious effect on the subsequent development of porcine NT embryos.

ACKNOWLEDGEMENTS. This study was supported by a Grants-in-Aid for Scientific Research (No. 12480248) from the Japan Society for the Promotion of Science. The authors thank Dr. Masaru Okabe (Genome Information Research Center, Osaka University) for the generous gift of pCXNEGFP and the staff members of the Ebetsu Meat Inspection Office (Hokkaido, Japan) for supplying the pig ovaries.

\section{REFERENCES}

1. Arat, S., Rzucidlo, S.J., Gibbons, J., Miyoshi, K. and Stice, S.L. 2001. Production of transgenic bovine embryos by transfer of transfected granulosa cells into enucleated oocytes. Mol. Reprod. Dev. 60: 20-26.

2. Atabay, E.C., Martinez Diaz, M.A., Dochi, O. and Takahashi, Y. 2001. Factors affecting enucleation rates of bovine and porcine oocytes after removal of cumulus cells by vortexing. $J$. Reprod. Dev. 47: 365-371.

3. Cheong, H.T., Ikeda, K., Martinez Diaz, M.A., Katagiri, S. and Takahashi, Y. 2000. Development of reconstituted pig embryos by nuclear transfer of cultured cumulus cells. Reprod. Fertil. Dev. 12: 15-20.

4. Cibelli, J.B., Stice, S.L., Golueke, P., Kane, J.J., Jerry, J., Blackwell, C., Ponce De Leon, F.A. and Robl, J.M. 1998. Transgenic bovine chimeric offspring produced from somatic cell-derived stem-like cells. Nat. Biotechnol. 16: 642-646.

5. Cunningham, E.P. 1999. The application of biotechnologies to enhance animal production in different farming systems. Livestock Prod. Sci. 58: 1-24.

6. Daniels, R., Hall, V. and Trounson, A.O. 2000. Analysis of gene transcription in bovine nuclear transfer embryos reconstructed with granulosa cell nuclei. Biol. Reprod. 63: 10341040.

7. Ikawa, M., Kominami, K., Yoshimura, Y., Tanaka, K., Nishimune, Y. and Okabe, M. 1995. A rapid and non-invasive selection of transgenic embryos before implantation using green fluorescent protein (GFP). FEBS Letters 375: 125-128.

8. Kato, M., Yamanouchi, K., Ikawa, M., Okabe, M., Naito, K. and Tojo, H. 1999. Efficient selection of transgenic mouse embryos using EGFP as a marker gene. Mol. Reprod. Dev. 54: 43-48.

9. Keefer, C.L., Baldassarre, H., Keyston, R., Wang, B., Bhatia, B., Bilodeau, A.S., Zhou, J.F., Leduc, M., Downey, B.R., Lazaris, A. and Karatzas, C.N. 2001. Generation of dwarf goat (Capra hircus) clones following nuclear transfer with trans- 
fected and nontransfected fetal fibroblasts and in vitro-matured oocytes. Biol. Reprod. 64: 849-856.

10. Kirchhof, N., Carnwath, J.W., Lemme, E., Anastassiadis, K., Scholer, H. and Niemann, H. 2000. Expression pattern of Oct-4 in preimplantation embryos of different species. Biol. Reprod. 63: $1698-1705$.

11. Koo, D.B., Kang, Y.K., Choi, Y.H., Park, J.S., Kim, H.N., Kim, T., Lee, K.K. and Han, Y.M. 2001. Developmental potential and transgene expression of porcine nuclear transfer embryos using somatic cells. Mol. Reprod. Dev. 58: 15-21.

12. Lai, L., Simonds, D.K., Park, K.W., Cheong, H.T., Greenstein, J.L., Im, G.S., Samuel. M., Bonk, A., Rieke, A., Day, B.N., Murphy, C.N., Carter, D.B., Hawley, R.J. and Prather, R.S. 2002. Production of $\alpha-1,3$-galactosyltransferase knockout pigs by nuclear transfer cloning. Science 295: 1089-1092.

13. Martínez Díaz, M.A., Ikeda, K. and Takahashi, Y. 2002. Effects of cycloheximide treatment and interval between fusion and activation on in vitro development of pig nuclear transfer embryos. Reprod. Fertil. Dev. 14: 191-197.

14. McCreath, K.J., Howcroft, J., Campbell, K.H.S., Colman, A., Schnieke, A.E. and King, A.J. 2000. Production of gene-targeted sheep by nuclear transfer from cultured somatic cells. Nature (Lond.) 405: 1066-1069.

15. Nichols, J., Zevnik, B., Anastassiadis, K., Niwa, H., KleweNebenius, D., Chambers, I., Scholer, H. and Smith, A. 1998. Formation of pluripotent stem cells in the mammalian embryo depends on the POU transcription factor Oct4. Cell 95: 379391.

16. Palmieri, S., Peter, W., Hess, H. and Scholer, R. 1994. Oct-4 transcription factor is differentially expressed in the mouse embryo during establishment of the first two extraembryonic cell lineages involved in implantation. Dev. Biol. 166: 259267.

17. Park, K.W., Cheong, H.T., Lai, L., Im, G.S., Kuhholzer, B., Bonk, A., Samuel, M., Rieke, A., Day, B.N., Murphy, C.N., Carter, D.B. and Prather, R.S. 2001. Production of nuclear transfer-derived swine that express the enhanced green fluorescence protein. Anim. Biotechnol. 12: 173-181.

18. Park, K.W., Kuholzer, B., Lai, L., Machaty, Z., Sun, Q.Y., Day, B.N. and Prather, R.S. 2001. Development and expression of the green fluorescent protein in porcine embryos derived from nuclear transfer of transgenic granulose-derived cells. Anim. Reprod. Sci. 68: 111-120.

19. Petters, R.M. and Wells, K.D. 1993. Culture of pig embryos. J. Reprod. Fertil. 48 (Suppl.): 61-73.

20. Schnieke. A.E., King, A.J., Ritchei, W.A., Mycock, K., Scott, A.R., Ritchie, M., Wilmut, I., Colman, A. and Campbell, K. 1997. Human factor IX transgenic sheep produced by transfer of nuclei from transfected fetal fibroblasts. Science 278: 2130 2133.

21. Shin, S.J., Lee, B.C., Park, J.I., Lim, J.M. and Hwang, W.S. 2001. A separate procedure of fusion and activation in an ear fibroblast nuclear transfer program improves preimplantation development of bovine reconstructed oocytes. Theriogenology 55: $1697-1704$.

22. Takahashi, Y. and First, N.L. 1992. In vitro development of bovine one-cell embryos: influence of glucose, lactate, pyruvate, amino acids and vitamins. Theriogenology 37: 963-978.

23. Tatham, B.G., Giliam, K.J. and Trounson, A.O. 1996. Electrofusion parameters for nuclear transfer predicted using isofusion contours produced with bovine embryonic cells. Mol. Reprod. Dev. 43: 306-312.

24. Uhm, S.J., Kim, N.H., Kim, T., Chung, H.M., Chung, K.H., Lee, H.T. and Chung, K.S. 2000. Expression of enhanced green fluorescent protein (EGFP) and neomycin resistant $(\mathrm{Neo}(\mathrm{R}))$ genes in porcine embryos following nuclear transfer with porcine fetal fibroblasts transfected by retrovirus vector. Mol. Reprod. Dev. 57: 331-337.

25. Wakayama, T., Perry, A.C., Zuccotti, M., Johnson, K.R. and Yanagimachi, R. 1998. Full-term development of mice from enucleated oocytes injected with cumulus cell nuclei. Nature (Lond.) 394: 369-374

26. Wells, D.N., Misica, P.M., Tervit, H.R. and Vivanco, W.H 1998. Adult somatic cell nuclear transfer is used to preserve the last surviving cow of the Enderby Island cattle breed. Reprod. Fertil. Dev. 10: 369-378.

27. Wilmut, L., Schnieke, A.E., McWhir, J., Kind, A.J. and Campbell, K.H.S. 1997. Viable offspring derived from fetal and adult mammalian cells. Nature (Lond.) 385: 810-813.

28. Yoshioka, K., Suzuki, C., Tanaka, A., Anas, I.M.K. and Iwamura, S. 2002. Birth of piglets derived from porcine zygotes cultured in a chemically defined medium. Biol. Reprod. 66: 112-119. 